\title{
中国科学院大连化学物理研究所
}

中国科学院大连化学物理研究所是一个在国内久负盛名、在国际上颇具影响的多学科综 合性研究所. 也是国家首批享有进出口自营权的科研院所. 其前身是建于 1907 年的南满铁 道株式会社中央试验所. 1949 年 3 月正式创建大连大学科学研究所. 1950 年定名为东北科 学研究所大连分所. 1952 年曾改名为中国科学院工业化学研究所. 1954 年又名为中国科学 院石油研究所. 1962 年正式命名为中国科学院大连化学物理研究所.

该所是一个应用研究与基础研究并重、有较强开发能力的、以承担国家和企业重大项目为 主的化学化工科研基地型研究所. 建所 50 年以来, 始终把国民经济建设需要作为所进行多方 面科学研究的主要内容, 并在催化化学、化学工程、化学激光和分子反应动力学, 以色谱为主的 近代分析化学等学科领域中屡有建树, 逐步形成了学科配套齐全、协同攻坚、敢于向科学尖端 攀登的务实态度与严谨作风. 相继培养和造就了一大批学术造诣深、在国内外享有较高声誉 的科学家和学术带头人以及一批高水平、高素质的研究、技术骨干. 被《科学》周刊杂志誉为东 亚地区“物理化学的温床”。全所现有职工 1000 多人, 其中研究员 85 人, 副研究员和高级工程 师 174 人, 中级研究人员 493 人, 全所有 160 多位高级专家由于他们对科技事业的贡献而享受 国务院颁发的政府特殊津贴. 有 10 位科学家先后当选为中国科学院院士. 目前, 分别在物理 化学、有机化学、化学工程、分析化学和生化工程专业领域内有博士和硕士学位授予权, 同时也 是博士生导师自主授予权的单位.

中国科学院大连化学物理研究所 ( 以下简称大连化物所) 的科研人员在几十年的实践中, 完成了许多重要研究项目, 并取得了重大的科研成果. 50 年代成功地将水煤气合成为液体燃 料; 60 年代研制了加氢异构化催化剂用于制取低冰点航空煤油, 开发了合成氨原料气净化新 流程; 70 年代研制了空间飞行器姿态控制催化剂, 航天氢氧燃料电池和长链烷烃脱氢催化剂 用于生产洗涤原料; 80 年代成功地开发了中空纤维膜氮氢分离技术用于从合成氨驰放气中回 收氢气; 90 年代在国际上率先研究开发了催化裂化干气中稀乙烯直接与苯反应制乙苯的新工 艺过程, 短波长氧碘化学激光的研究也达到了国际先进水平. 总之, 建所以来, 仅省部委以上 级别的成果就有 355 项, 其中国家级奖励 59 项, 申报国家发明专利 326 项.

现今所里的高技术产业以发展有自主知识产权的民族高技术产业为己任, 且已初具规模. 以农药中间体和新型特种催化材料为主要产品的凯飞高技术发展中心和国家催化工程技术研 究中心具有很好的发展势头, 膜技术国家工程研究中心已经国家有关部门批准成立, 其产业规 模将不断扩大.

1998 年底, 中国科学院决定进一步深化大连化物所的改革, 将其被列为中国科学院知识 创新工程首批启动的 12 个试点项目之一, 进行以研究所为单元的整体改革. 全所将从研究所 的体制、运行机制以及与国民经济和高技术产业的关系等方面, 探索建立面向 21 世纪知识经 济时代, 与国际接轨, 并且适应我国国情的现代研究所制度, 建立能够保证研究所健康持续发 展的运行机制, 为科学的发展和实现我国跨世纪发展目标做出更大贡献, 并培养和造就更多的 一流人才.

大连化物所的战略目标是: 研究工作上国际水平, 开发工作上效益规模, 创建世界第一流 研究所. 
大连化物所将在 “选控化学与工程”的学科方向上开展战略性、综合性、基础性、前瞻性的 创新工作. 基础研究以加深对化学反应本质及选择控制规律的认识为主, 应用研究将在资源 优化利用和环境友好的化学化工过程等方面开展工作. 改革后的研究室按照基础研究、应用 研究和重大项目设置, 其中, 基础研究: 催化基础国家重点实验室(催化反应化学、表面和催化 反应动态学、分子催化及吸附态化学、无机膜催化及催化新材料、热化学)、分子反应动力学国 家重点实验室 ( 分子束反应动力学、非稳态分子反应动力学、激光选键选态化学动力学、飞秒化 学)、色谱分析开放实验室 (国家色谱研究分析中心: 血液净化与分离、气相色谱、液相色谱、毛 细管电泳及生化分析); 重大项目: 化学激光研究室 (国家“八六三”计划短波长化学激光重点 实验室: 短波长化学激光)、新能源研究室 (燃料电池工程中心: 燃料电池技术); 应用研究: 分 析化学研究室(微型色谱技术、分子光谱、无机分析)、精细化工研究室(高分子有机合成、新型 农药和医药创制、烃类定向氧化)、生化工程研究室(生化反应工程、植物细胞及微生态工程、生 物医学工程)、天然气化工与应用催化研究室( 合成气制烯烃及分子篮应用、甲烷及低碳烷烃转 化新催化过程、干气综合利用及沸石催化材料、烃类选择氧化)、环境工程研究室(大气净化工 程、能源环境工程、污水治理工程).

改革工作分三个阶段进行, 即 1999 年 2 月前为起步阶段, 完成机构调整, 骨干人员、流动 人员的招聘上岗, 高技术产业公司人员到位; 1999 年底前为攻坚阶段, 完成后勤服务系统的改 革, 高技术公司的转制, 建立完整的现代研究所运行模式; 2000 年底前为完善总结阶段, 按照 新的体制和机制稳定运行, 不断总结经验、调整完善, 形成一批重大的科研成果, 从而实现改革 的总体目标.

( 本刊通讯员 艾生 戈央)

\section{来自大洋钻探 $(\mathrm{ODP})$ 的最新消息}

本刊讯 据汪品先院士 3 月 22 日来电: 大洋钻探计划( ODP) 184 航次的研究人员们正在我国 东沙群岛东南 $\left(19.58^{\circ} \mathrm{N}, 117.96^{\circ} \mathrm{E}\right)$, 水深约 $2093 \mathrm{~m}$ 处钻探第 3 井位. 自从在我国南沙群岛区域 开始钻探第 1 井位以来, 他们已提前顺利完成了预定计划. 由于天气宜人, 再加上出色的工 作, 钻探和运输等方面的工作都比预定计划进展得要快. 由于时间充裕, 他们决定对已经撤消 的井位进行钻探. 在 1145 井位, 他们已经获得了 $200 \mathrm{~m}$, 具有 $3 \mathrm{Ma}$ 以上记录的半深海沉积. 有 趣的是, 其沉积速率在逐渐增高. 最近的沉积速率要比 $3 \mathrm{Ma}$ 以前的沉积速率大约高 10 倍. 研 究人员们已开始探寻地球化学、古生物学和地球物理学记录之间的相互关系. 他们相信, 此次 大洋钻探最终一定会给人们一个有关我国南海变迁的满意结果.

在 1145 井位打 3 个钻孔之后, 他们将向西北方向航行, 探求我国南海的早期历史. 